\title{
Siberian river run-off and Late Quaternary glaciation in the southern Kara Sea, Arctic Ocean: preliminary results
}

\author{
Ruediger Stein, Frank Niessen, Klaus Dittmers, \\ Michael Levitan, Frank Schoster, Johannes Simstich, \\ Tatjana Steinke \& Oleg V. Stepanets
}

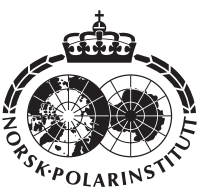

The extent of the Barents-Kara Ice Sheet during the eastern Last Glacial Maximum (LGM) is not yet fully known. A detailed echo-sounding survey performed during the Boris Petrov Expedition 2001 permitted the detailed mapping of part of it. Based on the profiling results, a southern connection between the LGM Barents-Kara Ice Sheet and a local ice sheet on Taymyr Peninsula appears to be unlikely. Based on sediment core data and profiling results, most of the terrigenous riverderived material accumulated in the estuaries during late Holocene times, whereas during early Holocene times of lowered sea level major amounts were transported further offshore and accumulated on the shelf. During the post-glacial sea level rise, the main depocentre migrated southward, reaching its present position no earlier than about 6 cal. Ky BP (or 5.2 Kya). Future studies of accelerator mass spectrometry (AMS) ${ }^{14} \mathrm{C}$-dated sediment cores will allow a detailed reconstruction of the variability of fluvial sediment discharge and the history of glaciation in the Kara Sea during late Quaternary times.

R. Stein, F. Niessen, K. Dittmers, F. Schoster \& T. Steinke, Alfred Wegener Institute for Polar and Marine Research, Columbustrasse, 27568 Bremerhaven, Germany; M. Levitan \& O. V. Spepanets, Vernadsky Institute of Geochemistry and Analytical Chemistry, RAS, Kosygin Street 19, Moscow 117 995, Russia; J. Simstich, GEOMAR, Wischhofstr. 1-3, 24148 Kiel, Germany.

Within the joint Russian-German project, Siberian River Run-Off (SIRRO), and following the two successful SIRRO expeditions in 1999 and 2000 (Stein \& Stepanets 2000, 2001), a third multidisciplinary scientific expedition with RV Akademik Boris Petrov was carried out in the $\mathrm{Ob}$ and Yenisei estuaries and adjacent inner Kara Sea in August-September 2001 (Figs. 1, 2; Stein \& Stepanets 2002). The overarching goal of this research project is understanding the biological, geochemical and geological processes related to the freshwater and sediment input by the Siberian rivers $\mathrm{Ob}$ and Yenisei and its impact on the present and past environments of the inner Kara Sea. During the expedition geological work concentrated on a detailed sediment profiling survey by means of an ELAC sediment echograph (operating frequency of $12 \mathrm{kHz}$, impulse length of $1 \mathrm{~ms}$, and $200 \mathrm{~W}$ transmitting power) as well as a GeoChirp sytem (2-8 kHz), and the sampling of bottom sediments using Multicorer, Giant Box Corer, and Gravity Corer. Location and core water depths are listed in Table 1.

The focus of the marine geological investigations of the material obtained during this expedition was twofold: first, the quantification and characterization of the supply of siliciclastic and organic material by the rivers $\mathrm{Ob}$ and Yenisei, its accumulation in the estuaries, its transfer onto the open Kara Sea shelf, and its changes in time and space; second, elucidation of the extent and history of the Late Quaternary glaciation 


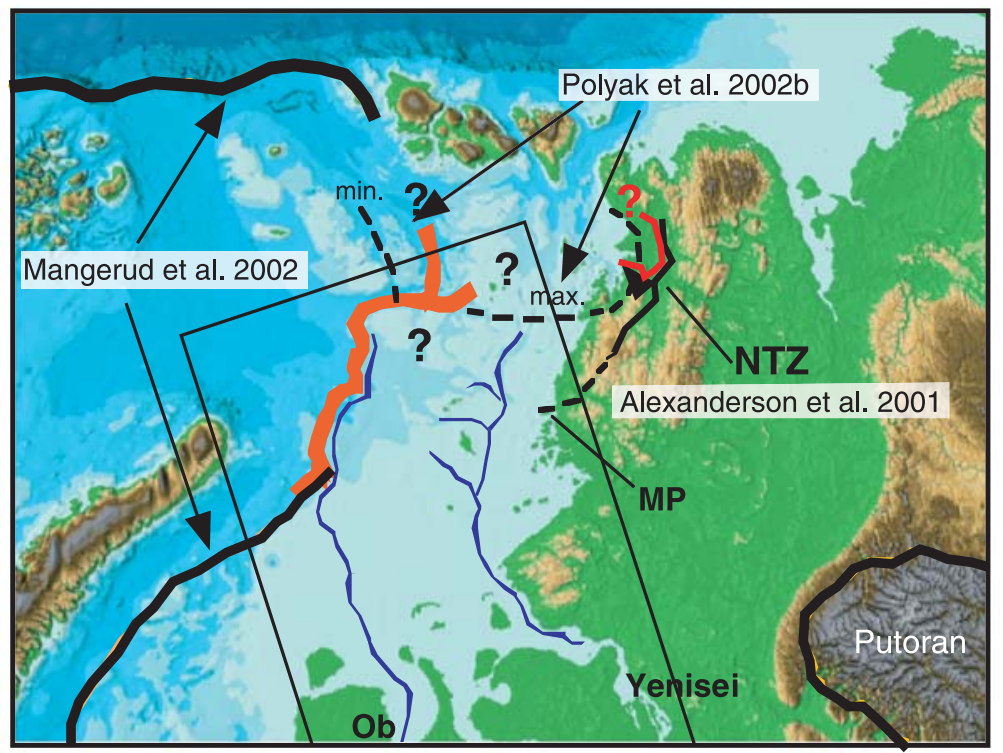

Fig. 1. Extent of the Late Weichselian glaciation in the Kara Sea (according to Mangerud et al. 2002). The "North Taymyr Ice-marginal Zone" (NTZ), related to Middle Weichselien glaciation, is shown on the Taymyr Peninsula; part of the NTZ marked in red is dated to LGM (according to Alexanderson et al. 2001). Maximum and minimum extension to the ice sheet at its eastern boundary as assumed by Polyak et al. (2002b) is shown. We marked the eastern boundary of the ice sheet mapped during our expedition (thick red line) as well as palaeo-channels related to the $\mathrm{Ob}$ and Yenisei. Rectangle frames our study area. MP= Michailova Peninsula.

in the southern Kara Sea. A major remaining uncertainty is how far the Last Glacial Maximum (LGM) ice extended towards the east (Svendsen et al. 1999; Polyak et al. 2000, 2002a, 2002b; Mangerud et al. 2002). It is still under debate whether the LGM Barents-Kara Ice Sheet has been connected with an ice sheet on northern Taymyr Peninsula. Alexanderson et al. (2001) describe a belt of end moraines on northern Taymyr Peninsula related to Middle Weichselian (50 - 60 Kya) glaciation - the "North Taymyr Icemarginal Zone" (NTZ), the western extension of which reached the Kara Sea near Michailova Peninsula (Fig. 1). In the north-east, however, part of the NTZ is related to the LGM glaciation.

Contemporaneously to our expedition and also addressing reconstruction of the extent and history of Late Quaternary glaciation in this area, a Kara Sea expedition has been carried out by Polyak et al. (2002a).

\section{Results and discussion}

According to the echo-sounding results, the $\mathrm{Ob}$ and Yenisei estuaries are characterized by a high penetration depth of the sediment profiler, indicating thick sequences of soft young (Holocene/post-glacial) sediments (acoustic Unit I) overlying the pre-Holocene bottom topography (acoustic Unit II) (Fig. 3; see Stein \& Stepanets 2000; for a detailed interpretation of the profile in relationship to the post-glacial sea level rise we refer to Dittmers et al. in press). Based on the lithological core description, the deposits of Unit I are predominantly fine-grained siliciclastic sediments of terrigenous origin, indicating the importance of riverine supply in the entire study area. The upper part of Unit I is bioturbated (Subunit Ia), underlain by laminated sediments (Subunit Ib). Marked by a distinct change in magnetic susceptibility and a distinct reflector in the sediment echograph profile, the boundary between the subunits is accelerator mass spectrometry (AMS) ${ }^{14} \mathrm{C}$-dated to about $10 \mathrm{cal}$. Ky BP (9 Kya) (Fig. 4; for AMS ${ }^{14} \mathrm{C}$ dates see Table 1). A similar change is also recorded in several cores from the Laptev Sea continental margin and is related to the final stage of the last deglaciation of the Putoran Massif, the major source area of terrigenous weathering products of basaltic material characterized by high magnetic susceptibility (Kleiber \& Niessen 2000; Stein \& Fahl 2000).

Maximum thicknesses of the Unit I (Holocene/post-glacial?) sediments of up to $20 \mathrm{~m}$ were recorded with the sediment profiler south of about $73^{\circ} 30^{\prime} \mathrm{N}$ (Fig. 3). These high accumulation rate areas are probably associated with the mixing zone of marine and riverine water, where large 


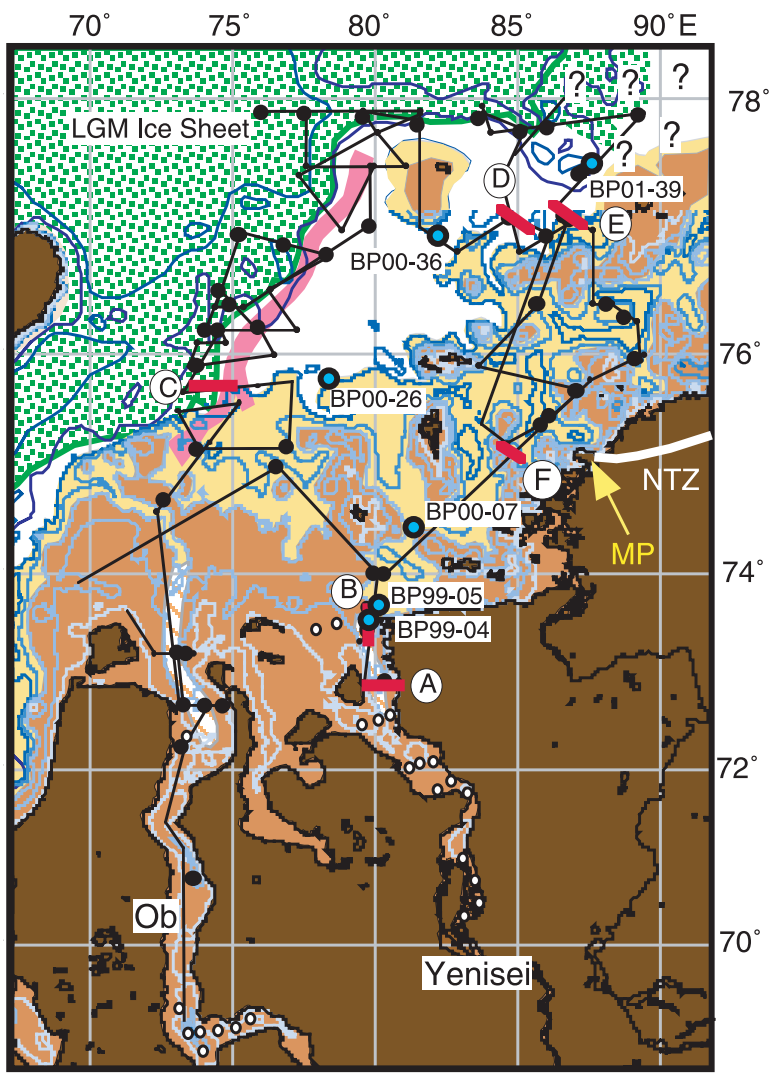

\section{Boris Petrov Expedition 2001}

- ELAC echo-sounding profiles

- Stations

- Stations with Gravity Cores

Extent of eastern LGM

Barents Sea Ice Sheet

Palaeo-river (LGM ?) channels

Land area at $11 \mathrm{cal} . \mathrm{Ky} \mathrm{BP}$

(sea level -50 m)

Land area at 9 cal. Ky BP

(sea level $-30 \mathrm{~m}$ )

Present land area

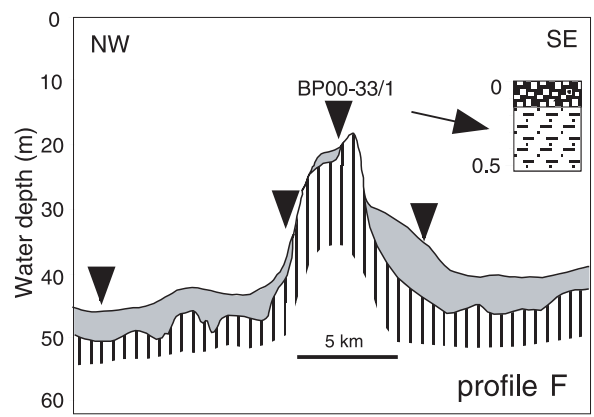

Fig. 2 (left). Map of the study area of the Akademik Boris Petrov Expedition 2001 in the inner Kara Sea and Ob and Yenisei estuaries, presenting the location of sampling sites and sediment echograph profiles. Locations of the sediment echo-sounding profiles A (shown in Fig. 3), B (Fig. 4), C (Fig. 6), D (Fig. 7) and E (in Fig. 9) and the location of the AMS ${ }^{14}$ C-dated sediment cores BP99-04/7, BP99-05/1, BP00-07/7, BP00-26/4, BP00-36/4, and BP01-39/2 are indicated. In addition, a profile F accross an end moraine-like structure and location of sediment cores (black triangles) are shown (see Stein \& Stepanets 2001 for more details). The sediments of the $0.55 \mathrm{~m}$ long core BP00-33/01 located on the top of the end moraine-like structure, consists of a diamicton overlying stiff clay. Based on the profiling results, the extent of the south-eastern margin of the Last Glacial Maximum (LGM) ice sheet and a LGM palaeo-river channel are shown. Early Holocene (about 9 cal. Ky BP and $11 \mathrm{cal} . \mathrm{Ky} \mathrm{BP}$ ) land area assuming a $30 \mathrm{~m}$ and $50 \mathrm{~m}$, respectively, lowered sea level in comparison to today (according to Fairbanks 1989). The map has been constructed using the $30 \mathrm{~m}$ and $50 \mathrm{~m}$ isolines of the modern bathymetry (and assuming no or negligible isostatic rebound); therefore, it should be only used as first approximation. MP=Michailova Peninsula; for NTZ see Fig. 1 .

amounts of dissolved and particulate matter sink to the bottom due to flocculation and coagulation ("marginal filter", according to Lisitzin 1995). It can be inferred from these observations that during late Holocene times, most of the finegrained terrigenous sediments had already been deposited in the estuaries, and only smaller amounts were being transported further offshore. Towards the north, as well as towards the flanks of the estuaries, the penetration depth of the sediment profiler sharply decreases, indicating a decrease in accumulation rates. In the Yenisei estuary, the northern edge of the marginal filter is at about $73^{\circ} 30^{\prime} \mathrm{N}$ (Figs. 2, 4). Although most of the riverine suspensions were probably accumulating in the estuaries, significant quantities must have bypassed the marginal filters, as suggested from sediment budget calculation based on sediment core and seismic profiling results (Dittmers et al. in press; Stein et al. in press).

The sediments of Unit II are more sandy and partly cross-bedded and-at least in the Yenesei-have much higher magnetic susceptibility values (Fig. 4). Occasionally wood fragments and pieces of wood occur. In the upper part of Unit II, correlating with higher magnetic 


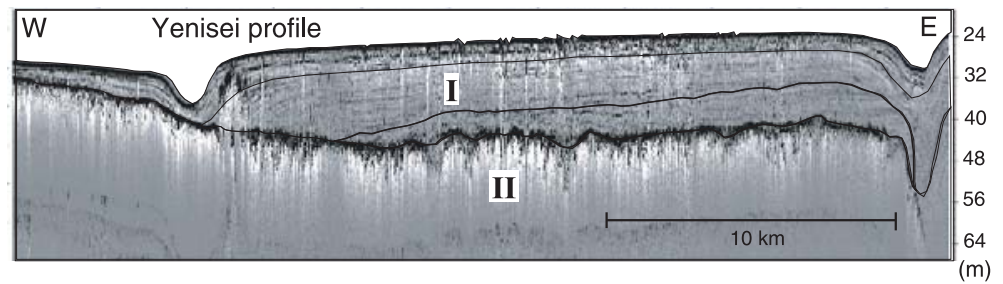

Fig. 3. High resolution GeoChirp profile from the central Yenisei estuary (for location see Fig. 2 , profile A). Roman numerals indicate acoustic units.

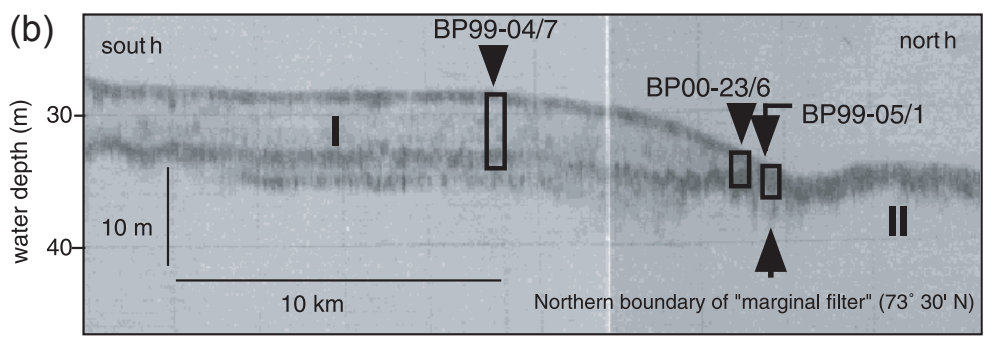

(a) Magnetic susceptibility

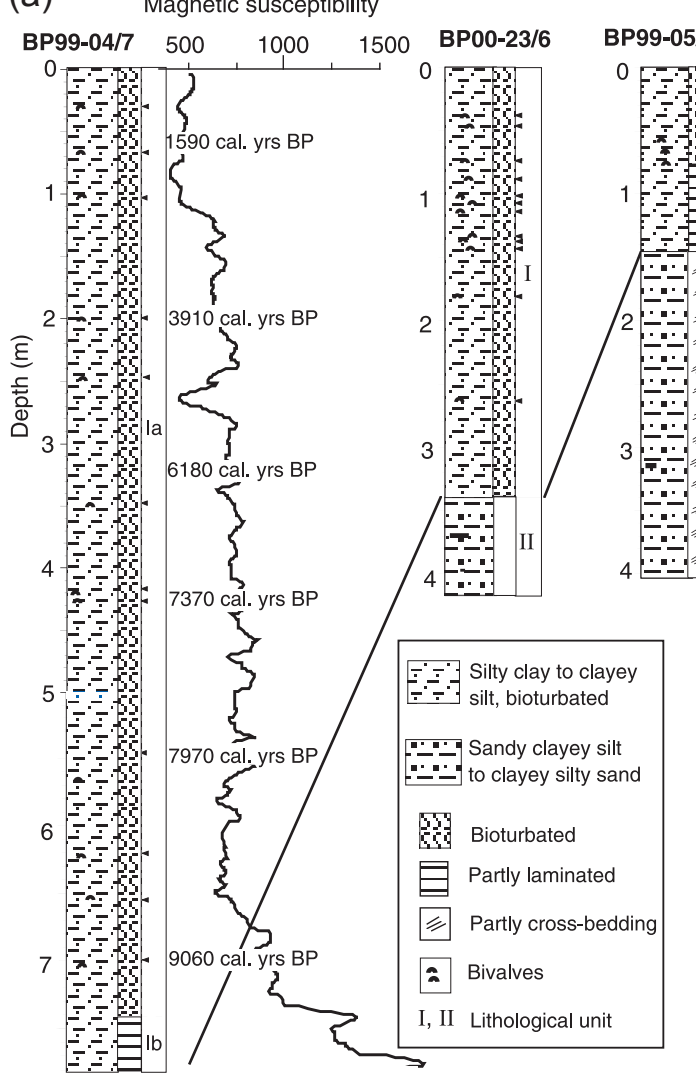

Magnetic susceptibility proportional factor of an applied magnetic field in relation to the magnetization in the sample (here expressed in $10^{-6} \mathrm{SI}$ units) and indicative for the sedimentological/mineralogical composition of the sediments (e.g. Kleiber \& Niessen 2000). Roman numerals indicate lithological units/subunits. Ages are given in calendar years BP.

susceptibility values, sandy intervals are more common than in the lower part. The sediments of Unit II may represent fluvial deposits of preHolocene age, formed during times of lowered sea level when the shallow Kara Sea shelf was

ig. 4. (a) Lithology and magcores BP99-04/7, BP99-05/1 and $\mathrm{BP} 00-23 / 6$, and (b) ELAC rom the Yechograph profile $B$ location of profile see Fig. 2). The magnetic susceptibility measured with a Multi-Sensor Core Logging System is

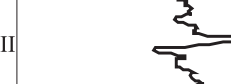
$15510 \mathrm{cal}$ yrs

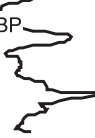

exposed. The high magnetic susceptibility values suggest source areas in the widespread basalts of the Putoran Plateau drained by the Yenisei River (see Kleiber \& Niessen 2000; Dittmers et al. in press; Stein et al. in press).

Sediment core data also indicate that in the early Holocene, when the sea level was approximately 30 to $50 \mathrm{~m}$ lower than today (Fig. 2), the main depocenter of the marginal filter was shifted much more to the north onto the shelf. Whereas today most of the river suspension accumulates in the estuaries, huge amounts of sediments were transported in channel systems towards the north, as indicated in the thick early Holocene sediments recorded at the AMS ${ }^{14} \mathrm{C}$-dated cores BP00-26, BP00-36 and BP01-39. Accumulation rates of total sediment reached very high values 


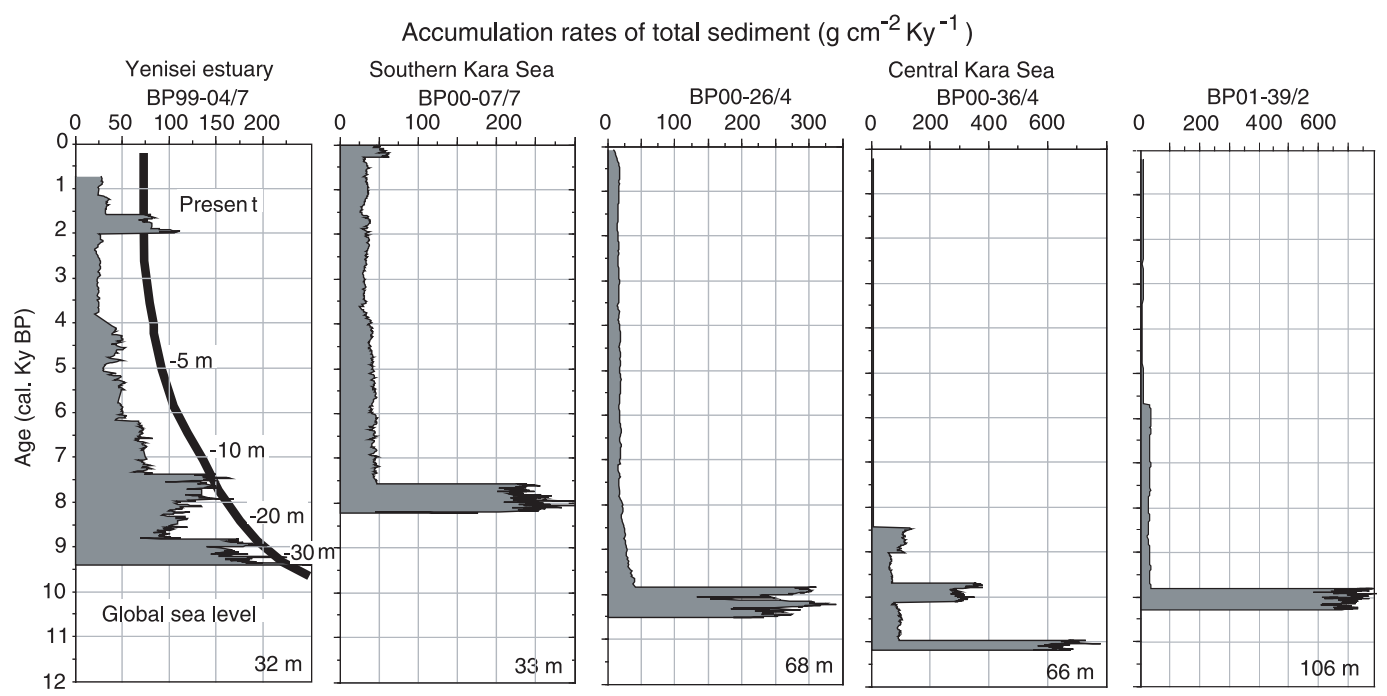

Fig. 5. Accumulation rate records of bulk (siliciclastic) sediments from the AMS ${ }^{14} \mathrm{C}$-dated sediment cores. For calculation of accumulation rates see Stein et al. (in press). The global sea level curve according to Fairbanks (1989) is shown.

of 300 to $>600 \mathrm{~g} \mathrm{~cm}^{-2} \mathrm{Ky}^{-1}$ (Fig. 5; see Table 1 for AMS ${ }^{14} \mathrm{C}$ dates.) Coastal erosion, which was especially important during early Holocene times when the shelf became widely flooded due to the post-glacial sea level rise (see Stein et al. in press and references therein), has to be considered as an additional sediment source. Thus, the early Holocene main depocenter was probably situated on the shelf more to the north and then migrated towards the south as the sea level rose. The final major break/reduction in accumulation rates did not occur contemporaneously at all sites. Whereas at the northern cores, this reduction in accumulation rates occurred near 10 cal. Ky BP (9 Kya),

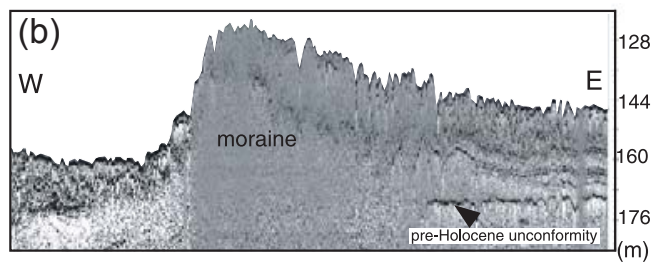

this reduction occurred near 7.5 cal. Ky BP (6.6 Kya) at the more southern core BP00-07 (Fig. 5). A similar evolution with a diachronous reduction in accumulation rates from north to south has been described for the Holocene Laptev Sea and is related to the Holocene transgression at the Eurasian continental margin (Bauch et al. 2001).

Our profiling records and sediment cores also give important new insight into the history and extent of the Late Quaternary glacial history (Stein et al. 2001). During the 2001 expedition, we could map parts of the as yet unknown southeastern boundary of the LGM ice sheet in great detail (Figs. 1, 2). The seafloor in the western part of our study area is strongly furrowed, which is interpreted as a relatively fresh (young) subglacial morphology (Fig. 6a). In numerous profiles this facies has a distinct boundary to the east which we interpret as the eastern boundary of the LGM ice sheet. Deeper penetrating chirp profiles reveal that young moraines overlying a

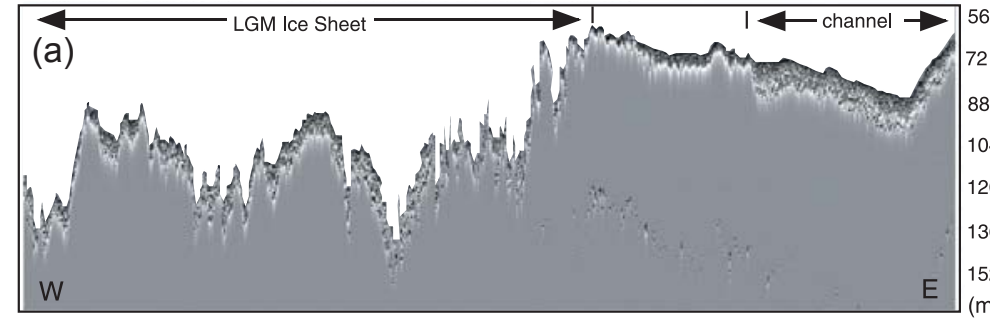

Fig. 6. Sediment echo-sounding profiles from the western study 104 area across the proposed eastern 20 margin of the LGM BarentsKara Ice Sheet (for location see Fig. 2, profile C). (a) ELAC 52 sediment echograph profile. (b) m) GeoChirp profile. 

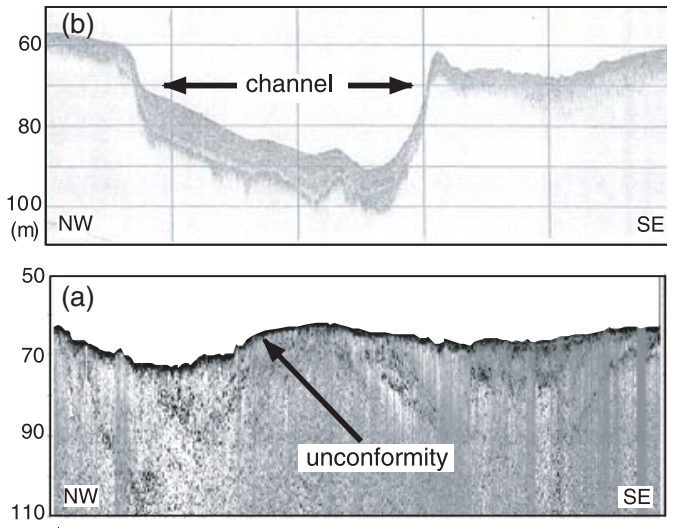

Fig. 7. ELAC sediment echograph profiles from the eastern study area south-east of the proposed eastern margin of the LGM Barents-Kara Ice Sheet (for location see Fig. 2, profile D).

pre-Holocene unconformity are associated with the strongly furrowed facies (Fig. 6b). The influence of a glacial ice sheet is also supported by sediment cores obtained from this area, which are composed of stiff, overconsolidated (?) clays and diamictons (Stein \& Stepanets 2002).

East/south of the mapped boundary of the LGM ice sheet, there is no evidence for a LGM ice sheet (i.e. no structures like end moraines and furrows were recorded in our profiles). Profiles from this area (Fig. 7a) are characterized by flat shelf surfaces forming a major unconformity overlain by very thin $(<2 \mathrm{~m})$ Holocene sediments. Holocene thickness can reach more than $10 \mathrm{~m}$, filling palaeo-valleys on the shelf (Fig. 7b). Submerged channels were identified on the shelf down to present water depth of up to $140 \mathrm{~m}$ (Fig. 8) in the north-eastern area. If eroded into the exposed shelf east of the ice sheet by river drainage possibly during LGM times, this would imply no or very little isostatic rebound after deglaciation. Because we cannot quantify isostatic rebound from our data two explanations remain possible: (1) the LGM ice sheet was very thin at its eastern boundary so that isostatic rebound was indeed negligible; or (2) the channels observed in deep water near the shelf edge today were formed as submarine extensions of palaeo-rivers across the exposed shelf. More data about palaeo-shorelines and locations of LGM palaeo-deltas are needed to answer the question conclusively. However, it is interesting to note that the profiling results show a major draining channel system in front of the glacial ice sheet (Fig. 6a). This channel can be mapped from about $73^{\circ} \mathrm{N}$ (40 $\mathrm{m}$ water depth) to $76^{\circ} 30^{\prime} \mathrm{N}$ (120 $\mathrm{m}$ water depth) and appears to be related to the LGM drainage of the Ob river deviated to the east by the LGM ice sheet boundary (Figs. 1, 2, 8).

Based on the echo-sounding profiles in the eastern part of our study area, there is no indication for a LGM ice cover in the area west and north-west of Taymyr Peninsula. That makes a southern connection between the LGM BarentsKara Sea Ice Sheet and a local ice sheet on Taymyr Peninsula unlikely (Fig. 1; see Svendsen et al. 1999; Alexanderson et al. 2001; Mangerud et al. 2002). Thus, it is suggested that the end morainelike structure with diamicton-like sediments on the top and underlying stiff (overconsoli-

Table 1. AMS ${ }^{14} \mathrm{C}$ datings performed on marine bivalves and one wood sample from cores BP99-04/7, BP99-05/1, BP0007/7, BP00-26/4, BP00-36/4, and BP01-39/2 at the Leibniz Laboratory for Radiometric Dating and Isotope Research, Kiel University. For marine bivalve samples, a reservoir correction of -440 years was used (see Mangerud \& Gulliksen 1975). Uncalibrated dates were transferred into calendar years according to Stuiver et al. (1998).

\begin{tabular}{|c|c|c|c|c|c|c|}
\hline Lab no. & $\begin{array}{l}\text { Sample } \\
\text { type }\end{array}$ & $\begin{array}{l}\text { Depth } \\
(\mathrm{cm})\end{array}$ & $\begin{array}{c}\text { AMS } \\
{ }^{14} \mathrm{C} \text { age } \\
\text { (yrs BP) }\end{array}$ & $\begin{array}{c}+/- \\
\text { (yrs) }\end{array}$ & $\begin{array}{c}\text { Age } \\
\text { corr. } \\
\text { (yrs BP) }\end{array}$ & $\begin{array}{l}\text { Age corr. } \\
\text { (cal. yrs } \\
\text { BP) }\end{array}$ \\
\hline \multicolumn{7}{|c|}{ Core BP99-04/7 (73² $24.9^{\prime} \mathrm{N}, 79^{\circ} 40.5^{\prime} \mathrm{E} ; 32 \mathrm{~m}$ water depth) } \\
\hline 2782 & biv. & 57 & 2070 & 25 & 1630 & 1586 \\
\hline KIA-10238 & biv. & 191 & 3980 & 30 & 3540 & 3911 \\
\hline 236 & biv. & 329 & 5800 & 40 & 5360 & 6178 \\
\hline 34 & biv. & 432 & 6890 & 45 & 6450 & 7373 \\
\hline $\mathrm{KI}$ & biv. & 53 & 7585 & 35 & 7145 & 7975 \\
\hline KIA-10230 & biv. & 700 & 8725 & 40 & 8285 & 9059 \\
\hline \multicolumn{7}{|c|}{ Core BP99-05/1 ( $73^{\circ} 30.1^{\prime} \mathrm{N}, 80^{\circ} 0.7^{\prime} \mathrm{E} ; 38 \mathrm{~m}$ water depth) } \\
\hline KIA-10244 & biv. & 55 & 2840 & 25 & 2400 & 2530 \\
\hline 42 & biv. & 72 & 3370 & 30 & 2930 & 3194 \\
\hline KIA & wood & 315 & 12880 & 90 & 12880 & 15512 \\
\hline \multicolumn{7}{|c|}{ Core BP00-07/7 (74 $39.5^{\prime} \mathrm{N}, 81^{\circ} 08.5^{\prime} \mathrm{E} ; 38 \mathrm{~m}$ water depth) } \\
\hline 037 & biv. & 31 & 650 & 25 & 210 & 268 \\
\hline 38 & iv. & 23 & 3955 & 35 & 3515 & 31 \\
\hline 39 & biv. & 488 & 7130 & 45 & 6690 & 7567 \\
\hline KIA-14040 & biv. & 690 & 7710 & 45 & 7270 & 8133 \\
\hline \multicolumn{7}{|c|}{ Core BP00-26/4 ( $75^{\circ} 42.5^{\prime} \mathrm{N}, 77^{\circ} 57.6^{\prime} \mathrm{E} ; 68 \mathrm{~m}$ water depth) } \\
\hline KIA-14044 & biv. & 257 & 9255 & 50 & 8815 & 9832 \\
\hline KIA-14045 & biv. & 375 & 9855 & 55 & 9415 & 10444 \\
\hline \multicolumn{7}{|c|}{ Core BP00-36/4 ( $76^{\circ} 57.7^{\prime} \mathrm{N}, 81^{\circ} 57.8^{\prime} \mathrm{E} ; 66 \mathrm{~m}$ water depth) } \\
\hline KIA-14046 & biv. & 70 & 8060 & 45 & 7620 & 8446 \\
\hline 047 & biv. & 144 & 8640 & 50 & 8200 & 90 \\
\hline & 10. & 19 & 9080 & 55 & 8640 & \\
\hline 049 & biv. & 330 & 9425 & 60 & 8985 & 10110 \\
\hline 50 & biv. & 408.5 & 10170 & 55 & 9730 & 10 \\
\hline KIA-14051 & biv. & 509 & 10200 & 55 & 9760 & 11117 \\
\hline \multicolumn{7}{|c|}{ Core BP01-39/2 (7706.7’ $\left.\mathrm{N}, 86^{\circ} 44.9^{\prime} \mathrm{E} ; 106 \mathrm{~m}\right)$} \\
\hline KIA-16863 & biv. & 51 & 5365 & 25 & 4925 & 5669 \\
\hline 364 & biv. & 179 & 9150 & 35 & 8710 & 9803 \\
\hline 865 & biv. & 280 & 9370 & 40 & 8930 & 9891 \\
\hline KIA-16866 & biv. & 525 & 10100 & 40 & 9660 & 11063 \\
\hline
\end{tabular}


Fig. 8. Water depths of major channels mapped by echosounding plotted against latitude.

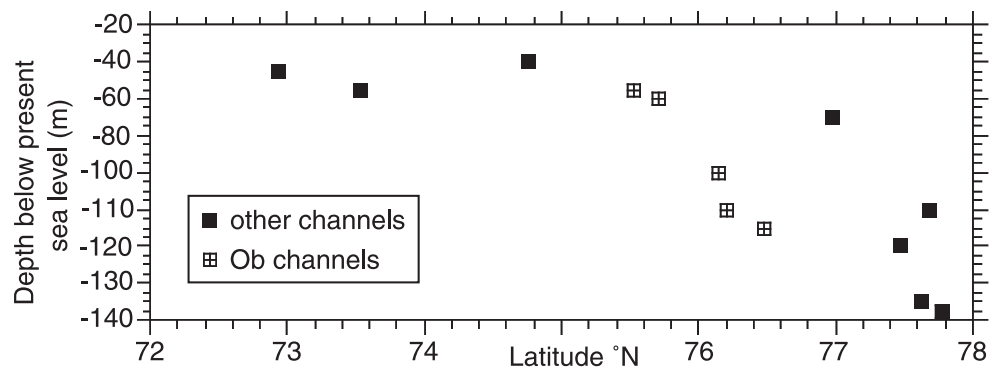

dated?) clay, recovered in this area near $75^{\circ} 17^{\prime} \mathrm{N}$, $84^{\circ} 13^{\prime}$ E during the 2000 expedition (Fig. 2; Stein \& Stepanets, 2001), probably represents older (? middle Weichselian) glaciogenic sediments which may be related to the seaward extention of the NTZ (Figs. 1, 2; Alexanderson et al. 2001).

The boundary of the LGM Ice Sheet in the north-eastern area under investigation remains questionable. This area is characterized by (in places more than $80 \mathrm{~m}$ ) thick well-stratified muds (Fig. 9). Here we offer two possible interpretations. (1) Older than LGM muds accumulated east of the LGM ice boundary and are undisturbed because the ice sheet did not extended to the area during the LGM. This would be similar to the western Laptev Sea (Kleiber \&

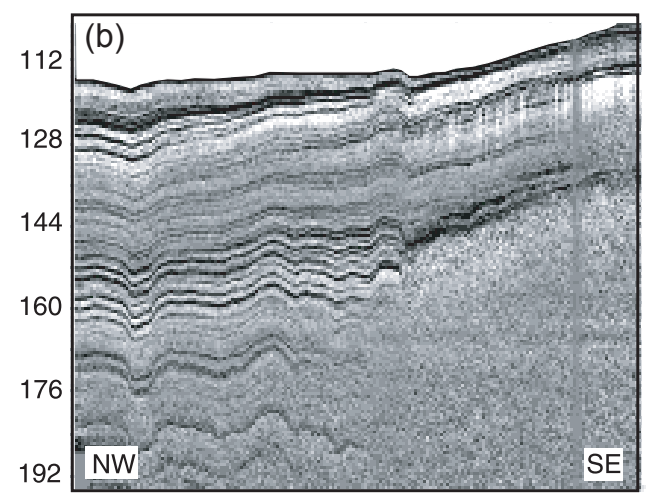

Niessen 1999, 2000), where thick sediments of Marine Oxygene Isotope Stages (MIS) 1 to 3 are overlaying the MIS 4 (?) glacial morphology. (2) The sediments are post-LGM in age and accumulated as pro-glacial muds in front of a retreating ice sheet. This would be similar to the southern Barents Sea where Gataullin et al. (2001) interpret thick, well-stratified muds as a time-transgressive unit accumulating in front of a retreating LGM ice sheet. If this interpretation is also valid for the Kara Sea, then it is surprising that thick stratified muds overlying LGM diamict are not observed west of our LGM ice boundary (Fig. 6) although the area has similar water depths than in the north-east, where thick muds are common (Fig. 9). Further studies on the sediment cores have to be performed to prove these hypothses. Also, it is too early to speculate about relative sea level changes and effects of post-LGM isostatic rebound in the area of investigation.

\section{Conclusions}

The coming detailed studies of the material obtained during the expedition will certainly give new insights into the understanding of biological, geochemical and geological processes related to the freshwater and sediment input by the Siberian rivers $\mathrm{Ob}$ and Yenisei and its impact on the environment of the inner Kara

(m)

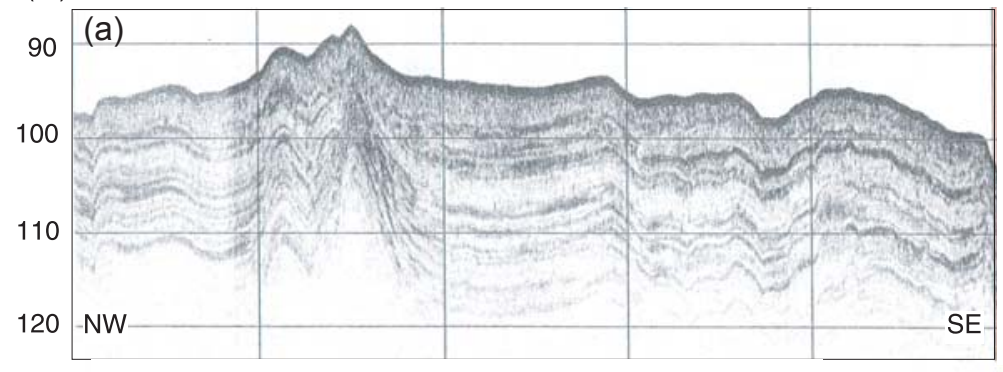

Fig. 9. Sediment echo-sounding profiles from the eastern study area, characterized by thick, well-stratified muds (for location see Fig. 2, profile E). (a) ELAC sediment echograph profile. (b) High resolution GeoChirp profile. 
Sea. The geochemical, sedimentological and stratigraphical analyses of the long sediment cores will allow the reconstruction of the Late Quaternary paleoenvironmental evolution in this area on a high resolution timescale. Furthermore, the combination of the detailed study of the long sediment cores (including absolute AMS ${ }^{14} \mathrm{C}$ dating) and the sediment profiling results will allow: (i) the study of the short- and long-term variability in river discharge and its relationship to climate and environmental changes; (ii) the calculation of the total sedimentary as well as organic carbon budgets for the $\mathrm{Ob}$ and Yenisei estuaries and the adjacent inner Kara Sea for the Holocene time interval; (iii) the determination of the age and size of the pre-Holocene river valleys and the estimation of pre-Holocene discharge rates; and (iv) the more detailed reconstruction of the extent and history of the Late Quaternary ice sheet of the southern Kara Sea.

Acknowledgements.-We thank M. Pirrung and M. Kraus for measuring the magnetic susceptibility of cores BP99-04/7 and BP99-05/1, and S.-I. Svendsen and one anonymous reviewer for constructive suggestions to improve the manuscript. Financial support by the German Ministry of Education, Science, Research and Technology (BMBF) and the Russian Foundation of Basic Research is gratefully acknowledged.

\section{References}

Alexanderson, H., Hjort, Chr., Möller, P., Antonov, O. \& Pavlov, M. 2001: The North Taymyr Ice-marginal Zone, Arctic Siberia-a preliminary overview and dating. Glob. Planet. Change 31, 427-445.

Bauch, H. A., Mueller-Lupp, T., Taldenkova, E., Spielhagen, R. F., Kassens, H., Grootes, P. M., Thiede, J., Heinemeier, J. \& Petryashov, V. V. 2001: Chronology of the Holocene transgression at the north Siberian margin. Glob. Planet. Change 31, 125-141.

Dittmers, K., Niessen, F. \& Stein, R. in press: Holocene sediment budget and sedimentary history for the Ob and Yenisei estuaries. In R. Stein et al. (eds.): Siberian river run-off in the Kara Sea: characterisation, quantification, variability, and environmental significance. Proceedings in Marine Sciences. Amsterdam: Elsevier.

Fairbanks, R. G. 1989: A 17000-year glacio eustatic sea level record: incfluence of glacial meting rates on the Younger Dryas event and deep-ocean circulation. Nature 342, 637642.

Gataullin, V., Mangerud, J. \& Svendsen, J. I. 2001: The extent of the Late Weichselian ice sheet in the southeastern Barents Sea. Glob. Planet. Change 31, 453-474.

Kleiber, H. P. \& Niessen, F. 1999: Late Pleistocene paleoriver channels on the Laptev Sea shelf-implications from subbottom profiling. In H. Kassens et al. (eds): Land-ocean systems in the Siberian Arctic: dynamics and history. Pp.
657-665. Berlin: Springer.

Kleiber, H. P. \& Niessen, F. 2000: Variations of continental discharge pattern in space and time-implications from the Laptev Sea continental margin. Int. J. Earth Sci. 89, 605-616.

Lisitzin, A. P. 1995: The marginal filter of the ocean. Oceanology 34, 671-682.

Mangerud, J., Astakhov, V. \& Svendsen, J. I. 2002: The extent of the Barents-Kara ice sheet during the Last Glacial Maximum. Quat. Sci. Rev. 21, 111-119.

Mangerud, J. \& Gulliksen, S. 1975: Apparent radiocarbon ages of recent marine shells from Norway, Spitsbergen, and Arctic Canada. Quat. Res. 5, 273-296.

Polyak, L., Gataullin, V., Gainanov, V., Gladysh, V. \& Goremykin, Y. 2002a: Kara Sea expedition yields insight into extent of LGM ice sheet. EOS 83, pp. 525 and 529.

Polyak, L., Gataullin, V., Okuneva, O. \& Stelle, V. 2000: New constraints on the limit of the Barents-Kara ice sheet during the Last Glacial Maximum based on borehole stratigraphy from the Pechora Sea. Geology 28, 611-614.

Polyak, L., Levitan, M., Khusid, T., Merklin, L. \& Mukhina, V. 2002b: Variations in the influence of riverine discharge on the Kara Sea during the last deglaciation and the Holocene. Glob. Planet. Change 32, 291-309.

Stein, R. \& Fahl, K. 2000: Holocene accumulation of organic carbon at the Laptev Sea continental margin (Arctic Ocean): sources, pathways, and sinks. Geo-Mar. Lett. 20 27-36.

Stein, R., Fahl, K. Dittmers, K., Niessen, F. \& Stepanets, O. V. in press: Holocene siliciclastic and organic carbon fluxes in the $\mathrm{Ob}$ and Yenisei estuaries and the adjacent inner Kara Sea: quantification, variability, and paleoenvironmental implications. In R. Stein et al. (eds.): Siberian river runoff in the Kara Sea: characterisation, quantification, variability, and environmental significance. Proceedings in Marine Sciences. Amsterdam: Elsevier.

Stein, R., Niessen, F., Dittmers, K., Levitan, M., Schoster, F., Simstich, J., Steinke, T., Stepanets, O. V. \& the Shipboard Scientific Party 2001: Late Quaternary history of river discharge und glaciation in the sourthern Kara Sea, Arctic Ocean: preliminary results. EOS Trans. 82(47) Abstract Volume. AGU Fall Meeting, San Francisco, 10 14 December 2001.

Stein, R. \& Stepanets, O. V. (eds.) 2000: Scientific cruise report of the Joint Russian-German Kara Sea expedition of RV "Akademik Boris Petrov" in 1999. Ber. Polarforsch. 360 .

Stein, R. \& Stepanets, O. V. (eds.) 2001: The GermanRussian project on Siberian River Run-Off (SIRRO). scientific cruise Report of the Kara Sea expedition "SIRRO 2000" of RV "Akademik Boris Petrov" and first results. Ber. Polarorsch. 393.

Stein, R. \& Stepanets, O. V. (eds.) 2002: Scientific cruise report of the Kara Sea expedition "SIRRO 2001" of $R V$ "Akademik Boris Petrov". Ber. Polarforsch. 419.

Stuiver, M., Reimer, P. J., Bard, E., Beck, J. W., Burr, G. S., Hughen, K. A., Kromer, B., McCormic, G., van der Plicht, J. \& Spurk, M. 1998: INTCAL 98 radiocarbon age calibration, 24000 - 0 cal BP. Radiocarbon 40, 1041-1083.

Svendsen, J. I., Astakhov, V. I., Bolshiyanov, D. Y., Demidov, I., Dowdeswell, J. A., Gautallin, V., Hjort. C., Hubberten, H. W., Larsen, E., Mangerud, J., Melles, M., Möller, P., Saarnisto, M. \& Siegert, M. J. 1999: Maximum extent of the Eurasian ice sheets in the Barents and Kara Sea region during the Weichselian. Boreas 28, 234-242. 